Int. Agrophys., 2021, 35, 307-317

INTERNATIONAL

\title{
Soil degradation mitigation in continental climate in young vineyards planted in Stagnosols**
}

\author{
Leon Josip Telak ${ }^{1} \mathbb{D}^{*}$, Paulo Pereira ${ }^{2}$, and Igor Bogunovic ${ }^{1} \mathbb{C}$ \\ ${ }^{1}$ Department of General Agronomy, University of Zagreb, Faculty of Agriculture, Zagreb 10000, Svetošimunska cesta 25, Croatia \\ ${ }^{2}$ Laboratory of Environmental Management, Mykolos Romeris University, Ateities st. 20, LT-08303 Vilnius, Lithuania
}

Received July 20, 2021; accepted October 21, 2021

\begin{abstract}
Intensive soil management in vineyards makes them vulnerable to the degradation of physical characteristics and soil erosion. Sustainable management practices in young vineyards should be adopted to ensure soil longevity and ecosystem stability. The aim of this research was to compare the effects of grass-covering and straw-mulching on the mitigation of soil degradation through the reduction of chemical and physical soil degradation and initial soil erosion. The soil sampling and rainfall simulations were performed in an immature vineyard, which was established in Stagnosol, in a semi-humid climate in order to study the intrinsic relationships between soil properties and soil degradation/erosion. The grass-covering treatment significantly increased the values of soil organic matter, mean weight diameter, water-stable aggregates, ponding and runoff times, and significantly reduced the values of water runoff, sediment concentration, sediment loss, carbon loss, phosphorous loss and as a consequence, increased the available phosphorous, and soil water content. The opposite result was observed for the tilled treatment. Straw-mulching did not affect soil properties, however it decreased water, soil, and nutrient losses. Grass-covering is highlighted as the most sustainable soil management strategy as it mitigates water, sediment and nutrient losses in young vineyards.

Keywords: Croatia, soil erosion, rainfall simulation, grasscovering, straw-mulching
\end{abstract}

\section{INTRODUCTION}

The unsustainability of current land management practices has been recognized in this research and is at the forefront of movements and legislation designed to

*Corresponding author e-mail: leonjosip.telak@gmail.com

**This work was supported by the Croatian Science Foundation through the project "Soil erosion and degradation in Croatia" (UIP-2017-05-7834) (SEDCRO) (2018-2023). ensure soil sustainability. United Nations Sustainable Development Goals include life protection, restoration, and the promotion of the sustainable use of terrestrial ecosystems as one of their goals, while the Soil Health and Food Mission Board proposed a mission "Caring for soil is caring for life", which aims to ensure that $75 \%$ of soils are healthy by 2030 . Additionally, one of the main elements of EU Soil Policy for land and soil in the EU Biodiversity Strategy for 2030 is that "it is essential to step up efforts to protect soil fertility, reduce soil erosion and the overuse of nutrients while increasing soil organic matter levels" this may be achieved through the adoption of sustainable soil management practices. Vineyards constitute an especially endangered type of land use from the point of view of soil degradation as the intensive soil management they are subjected to is inducing the degradation of certain physical characteristics and soil erosion. This may be observed in the higher reported soil erosion rates in vineyards in comparison with other orchards (Rodrigo-Comino, 2018), that produce olives (Taguas and Gomez, 2015; Bogunovic et al., 2020b), almonds (Martinez-Hernandez et al., 2017), apricots (Keestra et al., 2016), citrus (Cerda et al., 2009), avocados (Atucha et al., 2013), and also croplands (Schweizer et al., 2017; Bogunovic et al., 2018; Bogunovic et al., 2020b). Even though soil management characterized by the use of tillage and herbicide accelerates degradation in

(C) 2021 Institute of Agrophysics, Polish Academy of Sciences 
all environments (Bogunovic et al., 2019b), these effects are more pronounced in vineyards as vineyards are often established on steep slopes which have a bare soil surface. This is especially evident in young vineyards as previous work has revealed that higher soil erosion rates occur during the years immediately after vine plantation (Rodrigo-Comino et al., 2017). The reason for higher soil erosion rates in young vineyards is the bare soil before the leaf cover grows and roots systems are developed (Rodrigo-Comino et al., 2018). In addition, land levelling activities that are often performed with the planting of new vineyards were found to produce high runoff rates and soil losses (Ramos and Martinez-Casanovas, 2006), while contour-slope oriented rows showed a significant role in reducing runoff and soil losses (Bagagiolo et al., 2018).

Bare soils with a low soil organic matter (SOM) content are far more prone to water erosion, as may be observed in many studies, e.g. Arnaez et al. (2007), Garcia-Ruiz (2010), Novara et al. (2011). On the other hand, SOM is a factor closely related to favourable soil structure and aggregate stability (Ferreira et al., 2018; Piccolo et al., 1997), which also enhances infiltration (Gholoubi et al., 2019; Norton et al., 2006). Furthermore, an increase in SOM impacts the reduction of soil sealing and increases soil resistance to compaction (Braida et al., 2008), which in turn leads to lower soil erosion rates (Gholoubi et al., 2019; Norton et al., 2006). In addition, vegetation has been shown to play a significant role in the reduction of soil erosion rates (Gyssels et al., 2005), while grass-cover was also found to reduce both water and soil losses during extreme events that are predicted to become more frequent (Capello et al., 2020). However, the benefits of soil conservation only appear once the vegetation has reached its mature stage (Smets et al., 2008). The period between planting vines and permanent grass cover is recognized as being critical to soil and water losses. Therefore, mulches are recognized as being promising alternatives for soil conservation. Mulches have been shown to reduce soil erosion in the persimmon plantations (Cerdá et al., 2015), potato fields (Dőring et al., 2005), uncultivated soil (Jordán et al., 2010) and in vineyards (Prosdocimi et al., 2016). Mulches are often used to protect the soil surface during critical periods of plant establishment (Smets et al., 2008). However, their effectiveness depends on many factors like soil type, the steepness of the slope, mulch quantity, and rainfall erosivity (Poesen and Lavee, 1991; Smets et al., 2008).

Vine producers in Croatia use similar soil management techniques in coastal Mediterranean vineyards and inland vineyards under a moderate continental climate (Bogunovic et al., 2020a). The removal of the soil cover is performed even in humid areas as a common practice, where some vine producers have adopted the practice of grass covering every second row, that interchanges with the tillage every second year.
Regardless of management practices, the current vineyard soils in Croatia are endangered by a high degree of sediment loss (Bogunovic et al., 20020a; Telak and Bogunovic, 2020). It is expected that with climate change, the occurrences of high-intensity rainfalls will become more frequent and more intense (Panagos et al., 2017) and as a consequence there will be an increase in the frequency of severe water erosion and runoff processes (Poesen and Hook, 1997; Santos, 2000; Borga et al., 2011; Prosdocimi et al., 2016).

Therefore, sustainable management practices in young vineyards should be adopted to ensure soil longevity and ecosystem stability, as stated in the EU Soil Policy, especially in semi-humid areas where water is not a limiting factor.

This research aims to compare the effects of grasscovering and straw-mulching on the mitigation of soil degradation through a reduction in chemical and physical soil degradation and initial soil erosion in the young vineyard. An additional benefit of this research is that it was conducted on Stagnosol, a soil type with which few erosion studies have been conducted worldwide. Additionally, Stagnosol is the second most represented soil in Croatia, where soil erosion studies are rare.

\section{MATERIALS AND METHODS}

The research was conducted in a vineyard located in Orahovica, Croatia $\left(45^{\circ} 52^{\prime} \mathrm{N}, 17^{\circ} 88^{\prime} \mathrm{E}\right.$, average elevation $240 \mathrm{~m}$ a.s.1.) on an average slope of $6.5^{\circ}$ facing SW (Fig. 1). The study area has a moderate continental climate with an average annual precipitation value (1991-2017) of $938 \mathrm{~mm}$ where at least $50 \mathrm{~mm}$ of precipitation occurs in each month (Fig. 2). The highest precipitation occurs during September $(104.1 \mathrm{~mm})$, while February is the driest month with $54.5 \mathrm{~mm}$. The average yearly temperature is $11.5^{\circ} \mathrm{C}$, with January being the coldest month with an average temperature of $0.9^{\circ} \mathrm{C}$, while July is the warmest at $22.2^{\circ} \mathrm{C}$ (Meteorological and Hydrological Service of Croatia).

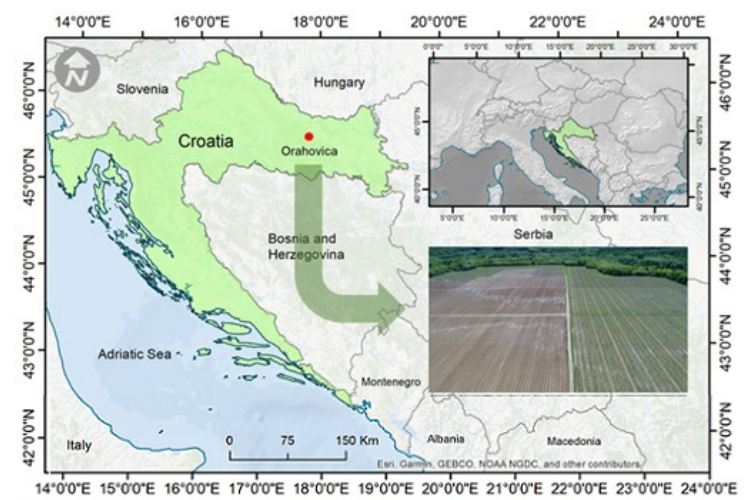

Fig. 1. Study area.

A young vineyard (4 years old) was chosen for the rainfall simulations in the study area. The grapevine variety is "Graševina" on the "Selection Oppenheim 4" rootstock. 


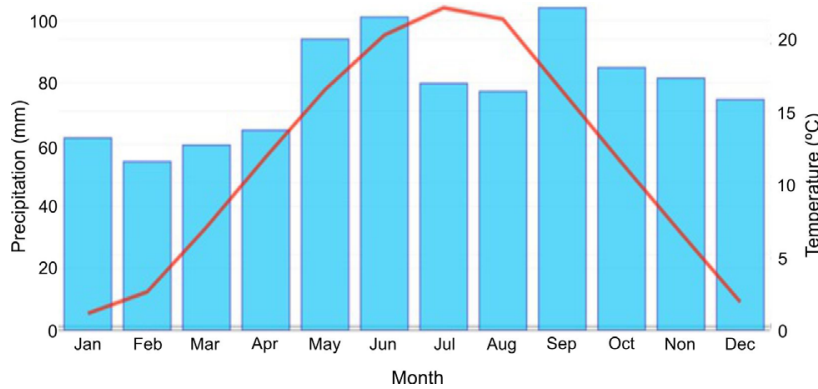

Fig. 2. Monthly average precipitation and temperature between 1999 and 2018. Data from Orahovica city meteorological station $\left(45^{\circ} 32^{\prime} \mathrm{N}, 17^{\circ} 54^{\prime} \mathrm{E}, 183 \mathrm{~m}\right.$ a.s.1.). The meteorological station is located $\sim 2 \mathrm{~km}$ from the studied vineyard.

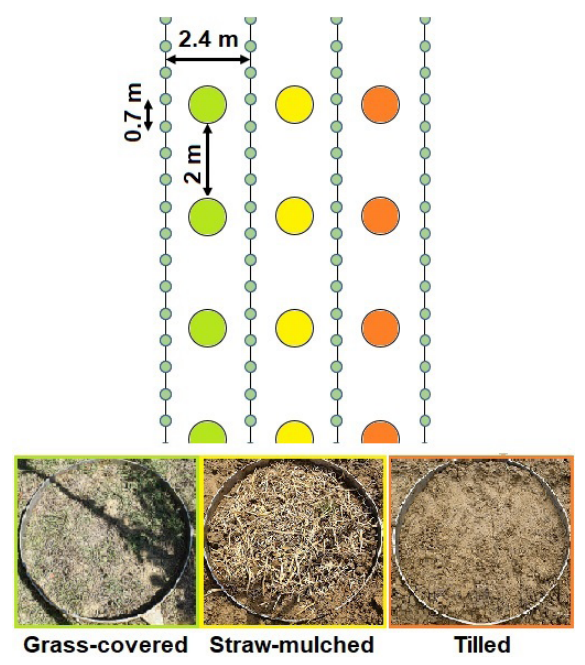

Fig. 3. Experimental design and treatments.

The vines were planted with $2.4 \mathrm{~m}$ spacing between the rows and $0.7 \mathrm{~m}$ spacing between the plants, while the rows were approximately $40 \mathrm{~m}$ long (Fig. 3). The traditional vineyard management in the area is comprised of shallow tillage (up to $10 \mathrm{~cm}$ ) which was performed using a rotoharrow machine for the first 2-3 years following vineyard establishment. Shallow tillage is performed twice a year as a weeding method (depending on grass growth) to reduce the competition for water between young vines and grasses. After the second or third year, depending on the initial growth of the vines, every second row of the vineyard is grass-covered, with a yearly rotation with tilled rows.

The soil of the study area has a silty clay loam texture, a low level of organic matter and is classified as Stagnosol (IUSS, 2015). The general soil properties are presented in Table 1.

The study compared three inter-row vineyard treatments (grass-covering, mulching, tillage). For each of the three treatments, eight representative plots $\left(0.785 \mathrm{~m}^{2}\right)$ were selected (twenty-four in total) following a paired plot strategy to achieve similar geomorphological conditions. Plots in different inter-row areas were positioned in line with each other, while in the same inter-row areas, the plots were located at approximately $2 \mathrm{~m}$ distance from each other
Table 1. General soil properties

\begin{tabular}{lrrrrrrrr}
\hline \multirow{2}{*}{$\mathrm{p}(\mathrm{x})$} & \multicolumn{3}{c}{ Soil texture } & & & & & \\
\cline { 2 - 7 } & Sand & \multicolumn{1}{c}{ Silt } & Clay & & SOM & AP & $\mathrm{K}_{2} \mathrm{O}$ & CEC \\
\hline mean & 5.00 & 78.00 & 17.00 & 4.85 & 1.73 & 22.15 & 17.21 & 21.67 \\
stdev & 1.30 & 4.20 & 7.30 & 0.50 & 0.24 & 7.56 & 4.53 & 2.50 \\
min & 4.00 & 71.00 & 10.00 & 3.97 & 1.43 & 11.58 & 12.42 & 18.76 \\
max & 8.00 & 82.00 & 25.00 & 5.51 & 2.08 & 32.35 & 23.57 & 25.99 \\
\hline
\end{tabular}

SOM - soil organic matter (\%), AP - available phosphorous $\left(\mathrm{mg} 100 \mathrm{~g} \mathrm{soil}^{-1}\right), \mathrm{K}_{2} \mathrm{O}$ - soil potassium content (mg $\left.100 \mathrm{~g} \mathrm{soil}^{-1}\right)$, $\mathrm{CEC}$ - cation exchange capacity $\left(\mathrm{cmol} \mathrm{kg}^{-1}\right)$.

(Fig. 3). The grass on the grass-covered treatment was not sown but instead was formed from spontaneously grown vegetation. Straw mulching was performed just before the rainfall simulations with $157 \mathrm{~g}$ of straw per plot $\left(0.785 \mathrm{~m}^{2}\right)$, which was equivalent to $2000 \mathrm{~kg} \mathrm{ha}^{-1}$, while in the tilled treatment, the last tillage operation was performed approximately six weeks before the simulations with a roto-harrow. A metal ring enclosed all twenty-four plots with a faucet $\left(1 \mathrm{~m}\right.$ in diameter; $\left.0.785 \mathrm{~m}^{2}\right)$ positioned to collect the overland flow. Before the rainfall simulations, at every plot, one soil core $\left(100 \mathrm{~cm}^{3}\right)$ and one undisturbed soil sample which was placed in rectangular boxes were taken from a depth of 0-10 cm, approximately $10 \mathrm{~cm}$ downslope of the catchment area. In total, twenty-four soil core samples and twenty-four undisturbed soil samples in rectangular boxes were taken. The soil core sampling was performed following the driving hammer method described in Parfitt et al. (2010), where soil core rings (widely recognized as Kopecky rings) were driven into the soil with hammer percussions. The undisturbed soil samples for the analysis of soil structure were taken by cutting the approximate size of the sampling box with a shovel to a $10 \mathrm{~cm}$ depth, digging out, and removing the edges by hand to ensure soil removal from shovel-disturbed aggregates. Following soil sampling, at each plot (eight per treatment; twenty-four in total), rainfall simulation was carried out using a calibrated UGT Rainmaker Rainfall Simulator (UGT, Munich, Germany). Calibration was ensured through the use of a plastic vessel and volumetric measurements of the rainfall which occurred prior to the actual simulations. Every rainfall simulation was performed with a rainfall intensity of $58 \mathrm{~mm} \mathrm{~h}^{-1}$ for $30 \mathrm{~min}$, resulting in $29 \mathrm{~mm}$ of rain over the $0.785 \mathrm{~m}^{2}$ plot area based on Bogunovic et al. (2020b). All simulations were carried out over a two-day period in May of 2019. During the simulations, at each plot, ponding time (PT) and runoff time (RT) were measured using a chronometer, while the overland flow was collected in plastic canisters for further analysis.

Soil core samples were used to analyse soil water content (SWC), water holding capacity (WHC), and bulk density (BD) following the core method (Casanova et al., 2016). Canisters containing the overland flow were weighed 
and the content was filtrated to quantify water runoff (WR), sediment concentration (SC), and sediment loss (SL). The values were up-scaled to represent values on a hectare scale to facilitate an easier interpretation of the data. Separated sediments were dried, milled, and passed through a $2 \mathrm{~mm}$ sieve in preparation for chemical analysis. Analysis of undisturbed soil samples started with a careful separation of soil from the aggregates, while avoiding breaking down formed aggregates and removing all non-soil fragments (Diaz-Zorita et al., 2002). Following the separation of aggregates, samples were air-dried until a constant mass was achieved, after which they were dry sieved in an auto sieve shaker (Impact Test Equipment Ltd., Ayrshire, UK) for $30 \mathrm{~s}$ (Le Bissonnais, 1996). The shaker was equipped with sieves that had the following radii: $8,5,4,2,1,0.5$, and $0.25 \mathrm{~mm}$. Each separated fraction was weighed, while the $>8 \mathrm{~mm}$ fraction was removed from further calculations because of the high degree of variability. The obtained data were used to calculate the mean weight diameter (MWD) using the following formula:

$$
M W D=\sum_{i=1}^{n} x i w i
$$

where: $x i$ is the mean diameter of any particular size range of aggregates separated by sieving, and wi is the weight of the aggregates in that size range as a fraction of the total dry weight of soil used (Blair et al., 2006). Part of the 1-2 mm fraction was separated for water-stable aggregate (WSA) analysis, while the rest was milled and passed through a $2 \mathrm{~mm}$ sieve in preparation for chemical analysis. A wet sieving apparatus (Eijkelkamp, Giesbeek, Netherlands) was used for the determination of WSA, following Eijkelkamp's wet sieving method based on the procedure of Kemper and Rosenau (1986).

A wet combustion procedure using $\mathrm{H}_{2} \mathrm{SO}_{4}$ and $\mathrm{K}_{2} \mathrm{Cr}_{2} \mathrm{O}_{7}$ was performed according to Walkley and Black (1934), it was used to determine SOM, which is in accordance with the IUSS (2015). The ammonium lactate extraction method developed by Egner et al. (1960) was used to extract the available phosphorous (AP). The solution was then analysed with a spectrophotometer according to a method devised by Samadi-Haybodi et al. (2013). In order to analyse the sediments, $100 \mathrm{mg}$ of each sample was weighed in tin foil which was then pressed around them to form a capsule, thereby ensuring that all of the air was excluded. Sediment analyses were then carried out with an Elementar Vario Macro CHNS analyser using a dry combustion method. Prepared sample capsules were then put into the autosampler of the machine, which carried out analyses by burning the samples in a helium oxygen-rich atmosphere, after which the gasses were passed through reduction tubes into the separation tubes and quantified.
Before data analyses were conducted, the Shapiro-Wilk test for normality was used to ensure the normal distribution of the data $(p>0.05)$. Out of fourteen measured variables, only three followed a normal distribution (BD, WHC, and RT). Following failed normality tests, the data sets were subjected to several transformation methods from which the Box-Cox method showed the highest success rate with eleven out of fourteen variables being normally distributed (excluding $M W D$, SOM, and AP). Variables that could not be normalized were analysed using the Kruskal-Wallis test, while variables that followed a normal distribution were analysed with a one-way ANOVA. Following the ANOVA and Kruskal-Wallis tests, the identified statistical differences $(p<0.05)$ were subjected to the Tukey LSD post hoc test for one-way ANOVA and two-tailed multiple comparisons of the p-value for the Kruskal-Wallis test, respectively. A principal component analysis (PCA) was applied to identify associations between the variables. A PCA based on the correlation matrix was performed using Box-Cox transformed data (highest normality data set). No rotation procedure was applied. All statistical analyses were carried out using Statistica 12 (StatSoft, Inc., 2013). A graphical visualization was performed using Plotly (Plotly Chart Studio).

\section{RESULTS}

Figure 4A and 4B show that soil management did not significantly impact bulk density (BD) and water holding capacity (WHC), as similar values may be observed among all three treatments. The soil water content (SWC) was significantly lower for the grass-covered treatment $(35.31 \%)$ as compared to the straw-mulched $(38.02 \%)$ and tilled (37.95\%) ones respectively (Fig. 4C). Soil management had a significant impact on mean weight diameter values (Fig. 4D) as a significantly higher value may be observed in the grass-covered treatment $(3.30 \mathrm{~mm})$ as compared to the straw-mulch $(2.61 \mathrm{~mm})$ and tilled $(2.63 \mathrm{~mm})$ treatments. There was no significant difference in the water-stable aggregates (WSA) among the treatments, as shown in Fig. 4E, although the highest range and variability values may be observed in the grass-covered treatment. The soil organic matter (SOM) content was significantly higher in the grass-covered treatment $(2.01 \%)$ in addition to the straw-mulched $(1.51 \%)$ and tilled $(1.52 \%)$ one, respectively (Fig. 4F). Finally, Fig. 4G shows a significantly lower value of available phosphorous (AP) in the grasscovered $\left(161.3 \mathrm{mg} \mathrm{kg}^{-1}\right)$ as opposed to the straw-mulched $\left(280.9 \mathrm{mg} \mathrm{kg}^{-1}\right)$ and tilled $\left(281.1 \mathrm{mg} \mathrm{kg}^{-1}\right)$ treatments.

Soil management had a significant impact on both ponding time (PT) and runoff time (RT) (Fig. 5A, B), where a significant difference may be observed between each treatment. The PT values were as follows: grass-covering $(268 \mathrm{~s})>$ straw-mulched $(98 \mathrm{~s})>$ tilled $(43 \mathrm{~s})$. The same pattern may be observed for RT: grass-covered (417 s) $>$ straw-mulched (239 s) > tilled (133 s). Figure 5C shows 

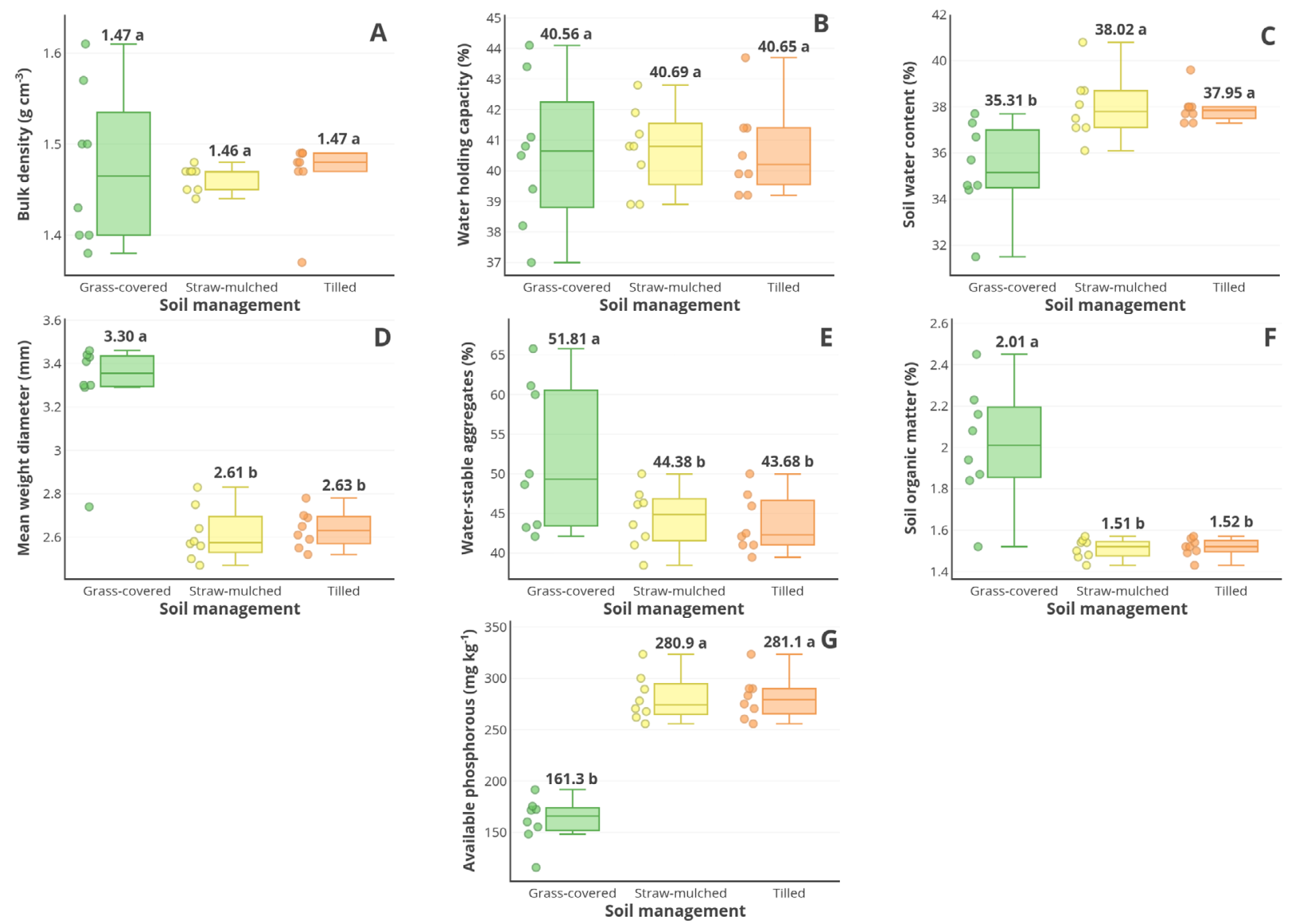

Fig. 4. Soil property distribution according the treatments. A) Bulk density, B) Water holding capacity, C) Soil water content, D) Mean weight diameter, E) Water-stable aggregates, F) Soil organic matter, G) Available phosphorous. Upper hanging bar (high edge), lower hanging bar (low edge), upper box line (quartile 3), line (median) and lower box line (quartile 1). Different lower-case letters represent significant differences between treatments $(\mathrm{p}<0.05)$.

that water runoff (WR) exhibited the opposite pattern of PT and RT where the highest value by a significant margin was observed in the tilled treatment $\left(163.22 \mathrm{~m}^{3} \mathrm{ha}^{-1}\right)$ this was followed by the straw-mulched $\left(139.98 \mathrm{~m}^{3} \mathrm{ha}^{-1}\right)$ one and the lowest value was found for the grass-covered treatment $\left(85.23 \mathrm{~m}^{3} \mathrm{ha}^{-1}\right)$. The highest sediment concentration (SC) by a significant margin was observed in the tilled treatment $\left(10.75 \mathrm{~g} \mathrm{~kg}^{-1}\right)$, this was followed by the straw-mulched $\left(4.84 \mathrm{~g} \mathrm{~kg}^{-1}\right)$ and grass-covered treatments $\left(2.91 \mathrm{~g} \mathrm{~kg}^{-1}\right)$ (Fig. 5D). Figure 5E shows that the measured sediment loss (SL) was lowest for the grass-covered treatment $(221.3 \mathrm{~kg}$ $\mathrm{ha}^{-1}$ ), followed by significantly higher values for the strawmulched treatment $\left(671.8 \mathrm{~kg} \mathrm{ha}^{-1}\right)$, and the highest value by a significant margin was based on the tilled treatment $\left(1764.9 \mathrm{~kg} \mathrm{ha}^{-1}\right)$. The observed $\mathrm{C}$ loss was significantly higher in the tilled treatment $\left(19.17 \mathrm{~kg} \mathrm{ha}^{-1}\right)$ in addition to the straw-mulched and grass-covered one (10.48 and 9.88 $\mathrm{kg} \mathrm{ha}^{-1}$, respectively) (Fig. 5F). Figure 5G shows the highest $\mathrm{P}$ loss for the tilled treatment $\left(766.8 \mathrm{~g} \mathrm{ha}^{-1}\right)$, followed by a significantly lower value in the straw-mulched treatment (324.7 $\mathrm{g} \mathrm{ha}^{-1}$ ), and the lowest value in the grass-covered treatment $\left(149.4 \mathrm{~g} \mathrm{ha}^{-1}\right)$.
The principal component analysis (PCA) revealed three major factors that explained $84.16 \%$ of the total variance, where factor 1 explained $59.36 \%$ while factors 2 and 3 explained 16.49 and $8.30 \%$ of it, respectively. Figure 5 displays the relationship between factors 1 and 2 . Water runoff (WR), sediment concentration (SC), sediment loss (SL), $\mathrm{C}$ loss, $\mathrm{P}$ loss, and available phosphorous (AP) were closely related. On the other side, soil organic matter (SOM), mean weight diameter $(M W D)$, water-stable aggregates (WSA), ponding time (PT), and runoff time (RT) were closely related to each other in a different group, which indicated a negative correlation between the two groups. Also, bulk density (BD) and water holding capacity (WHC) are on opposite sides, indicating a negative correlation between them (Fig. 6A). Additionally, soil water content (SWC) was closer to the WR group, possibly indicating a partial relationship to that group of variables.

The projection of the variable cases (Fig. 6) indicates different response for each treatment as cases formed separated groups. Each group was formed only from the cases of one treatment. We may clearly distinguish between the responses in soil properties and overland flow for treatments as groups do not overlap. Additionally, we may 

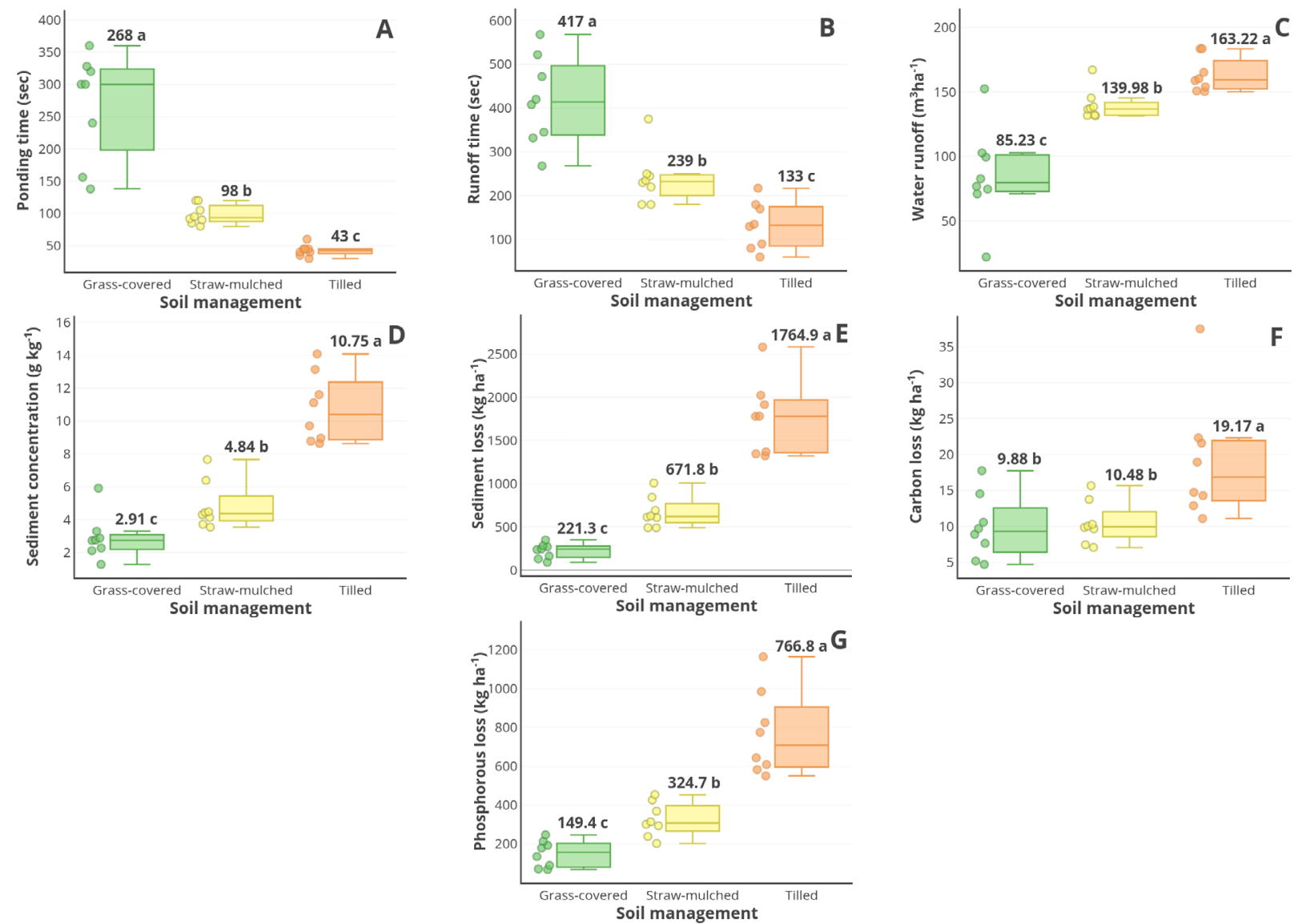

Fig. 5. Overland flow properties distribution according the treatments, A) Ponding time, B) Runoff time, C) Water runoff, D) Sediment concentration, E) Sediment loss, F) Carbon loss, G) Phosphorous loss. Upper hanging bar (high edge), lower hanging bar (low edge), upper box line (quartile 3), line (median) and lower box line (quartile 1). Different lower-case letters represent significant differences between treatments $(\mathrm{p}<0.05)$.

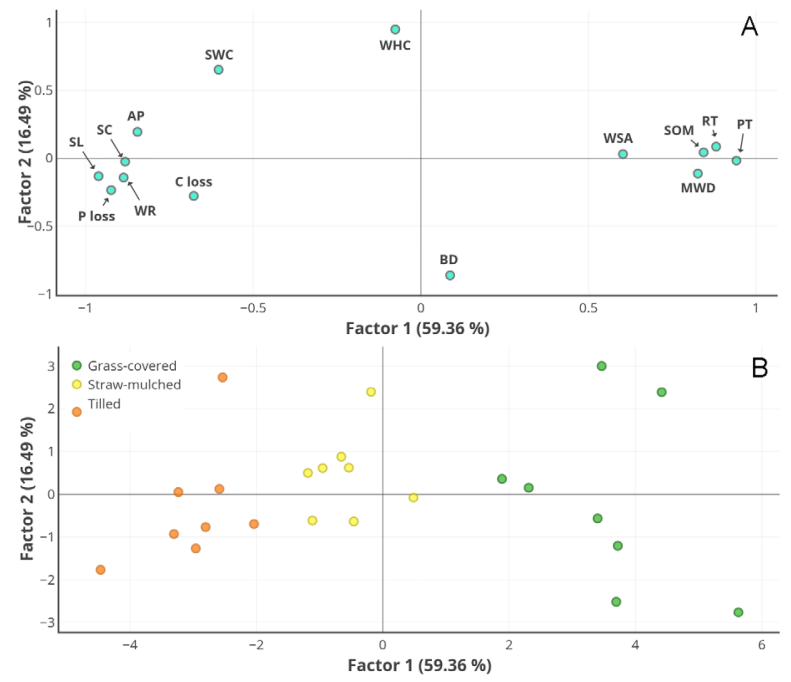

Fig. 6. A) Projection of variables through relation between Factors 1 and 2. Abbreviations: Bulk density (BD); water holding capacity (WHC); soil water content (SWC); mean weight diameter (MWD); water stable aggregates (WSA); soil organic matter (SOM); available phosphorous (AP); time to ponding (PT); time to runoff (RT); water runoff(WR), sediment concentration (SC); sediment loss (SL); Carbon loss (C loss), and available phosphorous loss (P loss). B) Projection of variable cases through relation between Factors 1 and 2 . observe the highest degree of inter-treatment variability for the grass-covered treatment as the group which has the most spread cases. The tilled treatment cases were loaded on the same side as the WR group of variables, indicating their high degree of positive correlation. On the other hand, the grass-covered treatment cases were loaded positively with the SOM group of variables, while the straw-mulching cases could be found between the two opposite groups.

\section{DISCUSSION}

The lack of significant differences in bulk density (BD) between the treatments may be attributed to machinery traffic. Although tillage loosens up the soil and reduces BD (Osunbitan et al., 2005; Bogunovic et al., 2019a), the state of soil BD changes with tractor traffic as the weight of the machinery compresses the soil even with a light tractor weight (Bogunovic et al., 2019a), thereby increasing BD during wheeling. Following tillage operation, the vineyard was crossed by machinery during the plant protection period, which increased BD in the tilled and straw-mulched plots, as observed by Capello et al. (2019). In the grasscovered treatment, BD was most likely already higher due to the absence of tillage and both natural (Telak et al., 2020) 
and machinery induced compaction (Soracco et al., 2015). The changes in $\mathrm{BD}$ were connected with water holding capacity (WHC) changes (Dec et al., 2008) as soil compaction modifies the pore system through changing pore size, shape, tortuosity, and continuity (Horton et al., 1994; Dec et al., 2008), which accounts for the lack of significant difference in WHC. The significantly lower soil water content (SWC) in the grass-covered treatment can be attributed to water usage by spontaneously grown vegetation, as the soil was only sampled in the upper $10 \mathrm{~cm}$ of the soil, which is the main zone of grass root growth. Similar results were reported by Zhang and Schilling (2006), while the opposite case may also be found (Biddoccu et al., 2017; Telak et al., 2021) as grass-cover increases albedo, reduces the heat flux into the soil, vapour flux, and evaporation (Lascano and Baumhardt, 1996). The significantly higher mean weight diameter $(M W D)$ in the grass-covered treatment results from tillage in the other two treatments, which breaks down soil structural aggregates and exposes them to the air (Zhang et $a l ., 2013$ ). As the structural aggregates encase soil organic matter (SOM) inside of them, their exposure to the air also increases the mineralization of the SOM through microbiological activity and increases the losses of SOM through soil respiration (Lal, 2013). Additionally, SOM acts as one of the main binding agents that cement soil particles into aggregates (Bronick and Lal, 2005; Šimanský et al., 2019), where the loss of SOM additionally impacts aggregate stability which may be seen in the reduction of the $M W D$ and waterstable aggregates (WSA). Furthermore, grasses increase SOM through rhizobium-deposition of different organic exudates and the degradation of dead leaves and plants at the end of their life cycle (Olson et al., 2014; Poeplau and Don, 2015). The fertilization of the soil is generally performed followed by tillage to incorporate fertilizers into the soil, as was the case in this vineyard, which explains the significantly higher level of available phosphorous (AP) in the straw-mulched and tilled treatment. The ponding time (PT) is a point in time during rainfall simulation and/or during natural rainfall where the precipitation exceeds the current infiltration rate of the soil and ponds begin to form on the surface. The increased infiltration rate also increases the PT as more water can permeate the soil before the threshold is reached. In this sense, $\mathrm{BD}$ was linked with changes in the infiltration rate (Horton et al., 1994; Green et al., 2003) that would eventually affect both PT and the runoff time (RT). These reported changes were due to the modification of the soil pore system under the effects of increased compaction, where, for example, larger pores that are temporally unstable cave in under the strain of increased compaction, modifying differential porosity, tortuosity, and pore orientation (Keller et al., 2017). In this study case, no significant differences in BD were observed among the treatments, but the different infiltration rates may be observed through significantly different PT, RT, and water runoff (WR) values. The different infiltration rates in this study were most likely the result of a more complex process like a change in pore orientation or tortuosity which results in no change in soil volume, e.g. BD (Horn et al., 2003; Soracco et al., 2015), as well as the positive impacts of soil cover (Jordan et al., 2010) along with better soil structure which was observed through higher $M W D$ values in the grass-covered treatment. The larger average size of the aggregates resulted in larger pores between the aggregates, which could account for the most favourable infiltration rate in the grass-covered treatment, as observed through the highest PT, RT and the lowest WR values as compared to the other treatments. Soil cover (mulch or grass) intercepts the kinetic energy of the raindrops, thereby protecting the soil aggregates from its destructive force. As Stagnosols, which are soils defined by a high content of silt, are prone to surface crusting, we postulate that surface cover also reduced crusting under the effects of rainfall, which protected the surface pores from collapse and resulted in the higher temperature infiltration of covered treatments. Similar results were reported by Biddoccu et al. (2013), where hydraulic conductivity in the inter-row area of the tilled plot was low due to soil crusting and compaction. Additionally, soil cover serves as a barrier that slows down water flow, resulting in the soil having a longer contact period with water and the ability to infiltrate it, resulting in higher RT values (Telak and Bogunovic, 2020). The significantly higher PT and RT values with significantly lower WR in the grass-covered treatment as compared to the other covered treatment (straw-mulched) which may be attributed to the higher density of the cover in grass-covering, and also better soil structure increased infiltration. The significant reduction in sediment concentration (SC) between the treatments from the tilled one to the grass-covered one may be attributed to the WR differences in surface cover and the sieving effect (Keesstra et al., 2016). In the tilled treatment, WR had its highest value by a significant margin, with a higher kinetic energy of water flow (higher sediment detachment capabilities) and a lack of the surface cover, which resulted in the highest SC value. Following tilled treatment, the straw-mulched treatment was characterized by a lower WR value and the presence of surface cover, which both reduced SC. Finally, in the grass-covered treatment, dense surface cover and the lowest WR value by a significant margin resulted in the lowest $\mathrm{SC}$ by a significant amount among the treatments. Sediment loss (SL) is a simple mathematical product derived from the multiplication of SC and WR, and as such, it is governed by the already stated explanations for both SC and WR, which resulted in significant differences of SL between all treatments as follows: tilled $>$ straw-mulched $>$ grass-covered. Despite the result of the highest impact of grass-covering on the reduction in SL, the lack of significant differences between grass-covered and straw-mulched treatments with regard to $\mathrm{C}$ loss is attributed to the significantly higher values of SOM in the grass-covered treatment where, the carbon content in the sediment was also relatively higher. 
On the other hand, P loss differences were mainly attributed to the differences in SL, where the differences between treatments in both properties followed the same pattern.

The projection of the variables (Fig. 5A) has confirmed the correlation between SOM, MWD, WSA, PT, and RT. Water-stable aggregates and $M W D$ increases with the increase in SOM (Bandyopadhyay et al., 2010; Karami et al., 2017; Yilmaz and Nmez, 2017), while the PT and RT correlation may be explained through an increase in the infiltration rate in better-structured soil. WR, SC, SL, AP, P loss, and $\mathrm{C}$ are negatively correlated on the opposite side of SOM, $M W D$, WSA, PT, and RT. This data aligns with the previously stated correlations, where SOM was described as a key factor for a better and more stable structure that increases infiltration and reduces WR, which is responsible for the sediment and nutrient losses. SWC was partially linked with unfavourable soil properties since a higher soil moisture content reduces the time before the soil reaches maximum WHC at which point, the infiltration rate was reduced, while WR increased. Even with organic P comprising $20-80 \%$ of the total soil phosphorous (Alamgir et al., 2012), it was negatively correlated with SOM due to fertilization that preceded tillage in the tilled and straw-mulched treatments. The same analysis also confirmed the previously mentioned negative correlation between BD and WHC.

The straw-mulched cases formed a group between the two groups which have already been described indicating the positive drift from tilled towards grass-covered treatments in their response. Based on their PCA loading values, the clear distinction between the groups may be noted in the projection of the variable cases (Fig. 5B). The tilled treatment was loaded on the same side as the WR group of variables, indicating the strong positive correlation of tilled treatment to the aforementioned variables. Conversely, grass-covered cases were loaded on the opposite side and closely correlated to the SOM group of variables. This is mainly due to the positive impacts of surface cover on reducing water, sediment, and nutrient losses, as no significant changes in soil properties were previously observed.

The abovementioned results imply that both soil management techniques that included soil cover are superior to the bare tilled soil in the study area from the point of view of soil and water conservation, where grass-covering should be highlighted as the optimal technique as it reduces the physical degradation of the soil as compared to strawmulched. Even though grass-covering significantly reduced SWC, this soil management technique should still be used, as the area is under a semi-humid climate where at least $50 \mathrm{~mm}$ of precipitation occurs every month of the year.

Despite the clear results of this study, its shortcomings should be addressed. The research was carried out on a small scale (one vineyard) using a rainfall simulator in only one season. Larger scale results are more useful for the scientific community, including studies carried out over many seasons, as in previous works, measured properties varied between the seasons. Additionally, rainfall simulator data is difficult to compare between the research studies due to the unstandardized methods and devices.

Nevertheless, the results of this study are still important to the scientific community. They provide insight into soil erosion rates in this specific area where there is a severe lack of data; they include a specific type of soil which is not well studied from the point of view of soil erosion; they describe in detail the intrinsic relationships of soil management, soil chemical and physical properties and the losses of water, soil and nutrients. This combination may prove beneficial in bridging the gaps in our understanding of soil degradation/erosion, and help with the design of more precise future models of soil erosion, and also help with decision-making policies such as the EU Soil Policy, and reaching the United Nations Sustainable Development goals of protecting life on the land.

\section{CONCLUSIONS}

1. Soil sampling and rainfall simulations were performed in the young vineyard established on Stagnosol in a semi-humid climate to study intrinsic relationships between soil properties and soil degradation/erosion and to ensure soil longevity and ecosystem stability. It was found that tillage degraded soil structure and soil organic matter, while grass-covering enhanced it. The grass-covering treatment significantly increased the values of soil organic matter, mean weight diameter, water-stable aggregates, ponding and runoff times, and significantly reduced the values of water runoff, sediment concentration, sediment loss, carbon loss, phosphorous loss, available phosphorous and soil water content. The opposite result was observed for the tilled treatment. Straw-mulching did not affect soil properties, but it did decrease water, soil, and nutrient losses.

2. The young vineyards established on Stagnosols have a high degree of potential erodibility and susceptibility to degradation, which may be mitigated with appropriate soil management that increases soil cover, reduces soil disturbance, and increases soil organic matter content.

3. From the point of view of environmental safety, ecosystem stability and soil longevity, the grass-covering treatment should be highlighted as the optimal choice as it reduces water, soil and nutrient losses, as well as the physical degradation of the soil, while increasing soil carbon stocks and preserving soil structure.

Conflict of interest: The authors declare no conflict of interest.

\section{REFERENCES}

Alamgir D.M., McNeill A., Tang C., and Marschner P., 2012. Changes in soil $\mathrm{P}$ pools during legume residue decomposition. Soil Biol. Biochem., 49, 70-77, https://doi.org/10.1016/j. soilbio.2012.01.031 
Arnáez J., Lasanta T., Ruiz-Flaño P., and Ortigosa L., 2007. Factors affecting runoff and erosion under simulated rainfall in Mediterranean vineyards. Soil Till. Res., 93, 324-334, https://doi.org/10.1016/j.still.2006.05.013

Atucha A., Merwin I.A., Brown M.G., Gardiazabal F., Mena F., Adriazola C., and Lehmann J., 2013. Soil erosion, runoff and nutrient losses in an avocado (Persea americana Mill) hillside orchard under different groundcover management systems. Plant Soil, 368, 393-406, https://doi.org/10.1007/ s11104-012-1520-0

Bagagiolo G., Biddoccu M., Rabino D., and Cavallo E., 2018. Effects of rows arrangement, soil management, and rainfall characteristics on water and soil losses in Italian sloping vineyards. Environ. Res., 166, 690-704, https://doi. org/10.1016/j.envres.2018.06.048

Bandyopadhyay P.K., Saha S., Mani P.K., and Mandal B., 2010. Effect of organic inputs on aggregate associated organic carbon concentration under long-term rice-wheat cropping system. Geoderma, 154, 379-386, https://doi. org/10.1016/j.geoderma.2009.11.011

Biddoccu M., Ferraris S., Cavallo E., Opsi F., Previati M., and Canone D., 2013. Hillslope vineyard rainfall-runoff measurements in relation to soil infiltration and water content. Procedia Environ. Sci., 19, 351-360, https://doi.org/10.1016/j. proenv.2013.06.040

Biddoccu M., Ferraris S., Pitacco A., and Cavallo E., 2017. Temporal variability of soil management effects on soil hydrological properties, runoff and erosion at the field scale in a hillslope vineyard, North-West Italy. Soil Till. Res., 165, 46-48, https://doi.org/10.1016/j.still.2016.07.017

Blair N., Faulkner R.D., Till A.R., Korschens M., and Schulz E., 2006. Long-term management impacts on soil $\mathrm{C}, \mathrm{N}$ and physical fertility: part I: broad balk experiment. Soil Till. Res., 91, 30-38, https://doi.org/10.1016/j.still.2005.11.002

Bogunovic I., Andabaka Z., Stupic D., Pereira P., Galic M., Novak K., and Telak L.J., 2019a. Continous grass coverage as a management practice in humid environment vineyards increases compaction and $\mathrm{CO}_{2}$ emissions but does not modify must quality. Land Degrad. Dev., 30(18), 2347-2359, https://doi.org/10.1002/ldr.3426

Bogunovic I., Fernandez M.P., Kisic I., and Marimon M.B., 2019b. Agriculture and grazing environments. Advances in Chemical Pollution, Environmental Management and Protection, 4, 23-70, https://doi.org/10.1016/bs.apmp.2019.07.005

Bogunovic I., Pereira P., Kisic I., Sajko K., and Sraka M., 2018. Tillage management impacts on soil compaction, erosion and crop yield in Stagnosols (Croatia). Catena, 160, 376-384, https://doi.org/10.1016/j.catena.2017.10.009

Bogunovic I., Telak L.J., and Pereira P., 2020a. Agriculture management impacts on soil properties and hydrological response in Istria (Croatia). Agronomy, 10(2), 282, https:// doi.org/10.3390/agronomy10020282

Bogunovic I., Telak L.J., Pereira P., Filipovic V., Filipovic L., Percin A., Durdevic B., Birkas M., Dekemati I., and Rodrigo-Comino J., 2020b. Land management impacts on soil properties and initial soil erosion processes in olives and vegetables crops. J. Hydrol. Hydromech., 68(4), 328337, https://doi.org/10.2478/johh-2020-0033
Borga M., Anagnostou E.N., Bloschl G., and Creutin J.D., 2011. Flash flood forecasting, warning and risk management: the HYDRATE project. Environ. Sci. Policy, 14, 834-844, https://doi.org/10.1016/j.envsci.2011.05.017

Braida J.A., Reichert J.M., Reinert D.J., and Sequinatto L., 2008. Soil elasticity as affected by water and oranic carbon content (in Portuguese). Rev. Bras. Cienc. Solo, 32, 477-485, https:// doi.org/10.1590/S0100-06832008000200002

Bronick C.J. and Lal R., 2005. Soil structure and management: a review. Geoderma, 124, 3-22, https://doi.org/10.1016/j. geoderma.2004.03.005

Capello G., Biddoccu M., and Cavallo E., 2020. Permanent cover for soil and water conservation in mechanised vineyards: A study case in Piedmont, NW Italy. Ital. J. Agron., 15(4), 1763, https://doi.org/10.4081/ija.2020.1763

Capello G., Biddoccu M., Ferraris S., and Cavallo E., 2019. Effect of tractor passes on hydrological and soil erosion processes in tilled and grassed vineyards. Water, 11, 2118, https://doi.org/10.3390/w11102118

Casanova M., Tapia E., Seguel O., and Salazar O., 2016. Direct measurement and prediction of bulk density on alluvial soils of central Chile. Chilean J. Agric. Res., 76, 105-113, https://doi.org/10.4067/S0718-58392016000100015

Cerdà A., González-Pelayo O., Giménez-Morera A., Jordán A., Pereira P., Novara A., Brevik E.C., Prosdocimi M., Mahmoodabadi M., and Keesstra S., 2015. The use of barley straw residues to avoid high erosion and runoff rates on persimmon plantations in Eastern Spain under low frequency - High magnitude simulated rainfall events. Soil Res., 547, 323-330, https://doi.org/10.1071/SR15092

Cerdà A., Morera A.G., and Bodí M.B., 2009. Soil and water losses from new citrus orchards growing on sloped soils in the western Mediterranean basin. Earth Surf. Process. Landf., 34, 1822-1830, https://doi.org/10.1002/esp.1889

Dec D., Domer J., Becker-Fazekas O., and Horn R., 2008. Effect of bulk density on hydraulic properties of homogenised and structured soil. J. Soil Sci. Plant Nutr., 8, 1-13.

Diaz-Zorita M., Perfect E., and Grove J.H., 2002. Disruptive methods for assessing soil structure. Soil Till. Res., 64, 3-22, https://doi.org/10.1016/S0167-1987(01)00254-9

Döring T.F., Brandt M., Heß J., Finckh M.R., and Saucke H., 2005. Effects of straw mulch on soil nitrate dynamics, weeds, yield and soil erosion in organically grown potatoes. Field Crop Res., 94, 238-249, https://doi.org/10.1016/j. fcr.2005.01.006

Egner H., Riehm H., and Domingo W.R., 1960. Untersuchungen uber die chemische Bodenanalyse als Grundlage fur die Beurteilung des Nährstoffzustandes der Böden. II. Chemische Extraktionsmethoden zur Phosphor- und Kaliumbestimmung. Kungliga Lantbrukshögskolans Annaler, 26, 199-215.

Ferreira T.R., Pires L.F., Wildenschild D., Brinatti A.M., Borges J.A.R., Auler A.C., and Dos Reis A.M.H., 2018. Lime application effects on soil aggregate properties: use of the mean weight diameter and synchrotron-based X-ray $\mu \mathrm{CT}$ techniques. Geoderma, 338, 585-596, https://doi.org/10.1016/j. geoderma.2018.10.035

García-Ruiz J.M., 2010. The effects of land uses on soil erosion in Spain: a review. Catena, 81, 1-11, https://doi.org/10.1016/j. catena.2010.01.001 
Gholoubi A., Emami H., and Caldwell T., 2019. Deforestation effects on soil aggregate stability quantified by the high energy moisture characteristic method. Geoderma, 355, 113919, https://doi.org/10.1016/j.geoderma.2019.113919

Green T.R., Ahuja L.R., and Benjamin J.G., 2003. Advances and challenges in predicting agricultural management effects on soil hydraulic properties. Geoderma, 116, 3-27, https://doi.org/10.1016/S0016-7061(03)00091-0

Gyssels G., Poesen J., Bochet E., and Li Y., 2005. Impact of plant roots on the resistance of soils to erosion by water: a review. Progress in Physical Geography, 29, 189-217, https://doi.org/10.1191/0309133305pp443ra

Horn R., Way T., Rostek J. 2003. Effects of repeated tractor wheeling on stress/strain properties and consequences on physical properties in structured arable soils. Soil Till. Res., 73(1-2), 101-106, https://doi.org/10.1016/S0167-1987(03)00103-X

Horton R., Ankeny M.D., and Allmaras R.R., 1994. Effects of compaction on soil hydraulic properties. In: Soil Compaction in Crop Production (Eds B.D. Soane, C. van Ouwerkerk). Elsevier: Amsterdam, The Netherlands, 141-165, https://doi. org/10.1016/B978-0-444-88286-8.50015-5

IUSS Working Group WRB., 2015. World reference base for soil resources 2014, update 2015: International soil classification system for naming soils and creating legends for soil maps. World Soil Resources Reports No. 106, 192.

Jordán A., Zavala L.M., and Gil J., 2010. Effects of mulching on soil physical properties and runoff under semi-arid conditions in southern Spain. Catena, 81, 77-85, https://doi. org/10.1016/j.catena.2010.01.007

Karami A., Homaee M., Afzalinia S., Ruhipour H., and Basirat S., 2012. Organic resource management: impacts on soil aggregate stability and other soil physico-chemical properties. Agriculture, Ecosys. Environ., 148, 22-28, https://doi.org/10.1016/j.agee.2011.10.021

Keesstra S., Pereira, P., Novara A., Brevik, E.C., Azorin-Molina C., Parras-Alcántara L., Jordán A., and Cerdà A., 2016. Effects of soil management techniques on soil water erosion in apricot orchards. Sci. Total Environ., 551, 357-366, https:// doi.org/10.1016/j.scitotenv.2016.01.182

Keller T., Colombi T., Ruiz S., Manalili M.P., Rek J., Stadelmann V., Wunderli H., Breitenstein D., Reiser R., Oberholzer H., Schymanski S., Romero-Ruiz A., Linde N., Weisskopf P., Walter A., and Or D., 2017. Long-term soil structure observatory for monitoring post-compaction evolution of soil structure. Vadose Zone J., 16, 1-16, https:// doi.org/10.2136/vzj2016.11.0118

Kemper W.D. and Rosenau R.C., 1986. Aggregate stability and size distribution. In: Methods of soil analysis (Ed. A. Klute). 425-442, https://doi.org/10.2136/sssabookser5.1.2ed.c17

Lal R., 2013. Carbon Sequestration, Terrestrial. Reference Module in Earth Systems and Environmental Sciences, 289-298, https://doi.org/10.1016/B978-0-12-409548-9.01211-2

Lascano R.J. and Baumhardt R.L., 1996. Effects of crop residue on soil and plant water evaporation in a dryland cotton system. Theor. Appl. Climatol., 54(1-2), 69-84, https://doi. org/10.1007/BF00863560

Le Bissonnais Y., 1996. Aggregate stability and assessment of soil crustability and erodibility: Theory and methodology. Eur. J. Soil Sci.,47,425-437, https://doi.org/10.1111/j.1365-2389.1996. tb01843.x
Martinez-Hernandez C., Rodrigo-Comino J., and Romero Diaz A., 2017. Impact of Lithology and Soil Properties on Abandoned Dryland Terraces During the Early Stages of Soil Erosion by Water in Southeast Spain. Hydrol. Process., 31(17), 3095-3109, https://doi.org/10.1002/hyp.11251

Meteorological and Hydrological Service of Croatia, 2019. Available at: https://meteo.hr/index_en.php

Norton L.D., Mamedov A.I., Huang C., and Levy G.J., 2006. Soil aggregate stability as affected by long-term tillage and clay type. Adv. Geoecol., 38, 422-429.

Novara A., Gristina L., Saladino S.S., Santoro A., and Cerdà A., 2011. Soil erosion assessment on tillage and alternative soil managements in a Sicilian vineyard. Soil Till. Res., 117, 140-147, https://doi.org/10.1016/j.still.2011.09.007

Olson K., Ebelhar S.A., and Lang J.M., 2014. Long-term effects of cover crops on crop yields, soil organic carbon stocks and sequestration. Open J. Soil Sci., 4, 284-292, https://doi. org/10.4236/ojss.2014.48030

Osunbitan J.A., Oyedele D.J., and Adekalu K.O., 2005. Tillage effects on bulk density, hydraulic conductivity and strength of a loamy sand soil in southwestern Nigeria. Soil Till. Res., 82(1), 57-64, https://doi.org/10.1016/j.still.2004.05.007

Panagos P., Ballabio C., Meusburger K., Spinoni J., Alewell C., and Borrelli P., 2017. Towards estimates of future rainfall erosivity in Europe based on REDES and WorldClim datasets. J. Hydrol., 548, 251-262, https://doi.org/10.1016/j. jhydrol.2017.03.006

Parfitt R.L., Ross C., Schipper L.A., Claydon J.J., Baisden W.T., and Arnold G., 2010. Correcting bulk density measurements made with driving hammer equipment. Geoderma, 157(1-2), 46-50, https://doi.org/10.1016/j.geoderma.2010.03.014

Piccolo A., Pietramellara G., and Mbagwu J.S.C., 1997. Use of humic substances as soil conditioners to increase aggregate stability. Geoderma, 75, 267-277, https://doi.org/10.1016/ S0016-7061(96)00092-4

Plotly Chart Studio, 2020. Available online: https://chart-studio. plotly.com/

Poeplau C. and Don A., 2015. Carbon sequestration in agricultural soils via cultivation of cover crops - a meta-analysis. Agriculture, Ecos. Environ., 200, 33-41, https://doi.org/10.1016/j. agee.2014.10.024

Poesen J.W.A. and Hooke J.M., 1997. Erosion, flooding and channel management in the Mediterranean environments of southern Europe. Prog. Phys. Geogr., 21, 157-199, https:// doi.org/10.1177/030913339702100201

Poesen J.W.A. and Lavee H., 1991. Effects of size and incorporation of synthetic mulch on runoff and sediment yield from interrills in a laboratory study with simulated rainfall. Soil Till. Res., 21, 209-223, https://doi.org/10.1016/0167-1987(91)90021-O

Prosdocimi M., Jordán A., Tarolli P., Keesstra S., Novara A., and Cerdà A., 2016. The immediate effectiveness of barley straw mulch in reducing soil erodibility and surface runoff generation in Mediterranean vineyards. Sci. Total Environ., 547, 323-330, https://doi.org/10.1016/j.scitotenv.2015.12.076

Ramos M.C. and Martínez-Casasnovas J.A., 2006. Nutrient losses by runoff in vineyards of the Mediterranean Alt Penedès region (NE Spain). Agric. Ecos. Environ., 113(1-4), 356-363, https://doi.org/10.1016/j.agee.2005.10.009

Rodrigo-Comino J., 2018. Five decades of soil erosion research in "terroir". The State-of-the-Art. Earth Sci. Rev., 179, 436447, https://doi.org/10.1016/j.earscirev.2018.02.014 
Rodrigo-Comino J., Brings C., Iserloh T., Casper M.C., Seeger M., Senciales J.M., Brevik E.C., Ruiz-Sinoga J.D., and Ries J.B., 2017. Temporal changes in soil water erosion on sloping vineyards in the Ruwer-Mosel Valley. The impact of age and plantation works in young and old vines. J. Hydrol. Hydromech., 65, 402-409, https://doi.org/10.1515/johh-2017-0022

Rodrigo-Comino J., Novara A., Gyasi-Agyei Y., Terol E., and Cerdà A., 2018. Effects of parent material on soil erosion within Mediterranean new vineyard plantations. Engin. Geolog., 246, 255-261, https://doi.org/10.1016/j.enggeo.2018.10.006

Samadi-Haybodi A., Taheri Saffar H., Khodadoust S., Nasrollahzadeh Sarvi H., and Najafpour S., 2013. Study on different forms and phosphorous distribution in the coastal surface sediments of Southern Caspian Sea by using UVVis spectrophotometry. Spectrochim. Acta A: Molecular and Biomolecular Spectroscopy, 113, 67-71, https://doi. org/10.1016/j.saa.2013.04.071

Santos M.J., 2000. The evolution of maximum precipitations in 24 hours throughout the XXth Century in Alicante (in Spanish). In: Meeting on Detection and Modelling of Recent Climate Change and its Effects on a Regional Scale. Universitat Rovirai Virgili, Tarragona, Spain.

Schweizer S.A., Fischer H., Haring V., and Stahr K., 2017. Soil structure breakdown following land use change from forest to maise in NorthWest Vietnam. Soil Till. Res., 166, 10-17, https://doi.org/10.1016/j.still.2016.09.010

Smets T., Poesen J., and Knapen A., 2008. Spatial scale effects on the effectiveness of organic mulches in reducing soil erosion by water. Earth Sci. Rev., 89, 1-12, https://doi. org/10.1016/j.earscirev.2008.04.001

Soracco C.G., Lozano L.A., Villarreal R., Palancar T.C., Collazo D.J., Sarli G.O., and Filgueira R.R., 2015. Effects of compaction due to machinery traffic on soil pore configuration. Rev. Bras. Cienc. Solo, 39(2), https://doi.org/ 10.1590/01000683rbcs20140359

Statsoft Inc., 2013. STATISTICA (data analysis software system), version 12. www.statsoft.com
Šimansky V., Juriga M., Jonczak J., Uzarowicz L., and Stepien W., 2019. How relationships between soil organic matter parameters and soil structure characteristics are affected by the long-term fertilisation of a sandy soil. Geoderma, 342, 75-84, https://doi.org/10.1016/j.geoderma.2019.02.020

Taguas E.V. and Gómez J.A., 2015. Vulnerability of olive orchards under the current CAP (Common Agricultural Policy) regulations on soil erosion: a study case in Southern Spain. Land Use Policy, 42, 683-694, https://doi.org/10.1016/j. landusepol.2014.09.001

Telak L.J., Pereira P., and Bogunovic I., 2021. Management and seasonal impacts on vineyard soil properties and the hydrological response in continental Croatia. Catena, 202, 105267, https://doi.org/10.1016/j.catena.2021.105267

Telak L.J., Pereira P., Ferreira C.S.S., Filipovic V., Filipovic L., and Bogunovic I., 2020. Short-term impact of tillage on soil and the hydrological response within a fig (ficus carica) orchard in Croatia. Water, 12, 3256, https://doi.org/10.3390/ w12113295

Telak L.J. and Bogunovic I., 2020. Tillage-induced impacts on the soil properties, soil water erosion, and loss of nutrients in the vineyard (Central Croatia). J. Cent. Eur. Agric., 21(3), 589-601, https://doi.org/10.5513/JCEA01/21.3.2810

Walkley A.J. and Black I.A., 1934. Estimation of soil organic carbon by the chromic acid titration method. Soil Sci., 37, 29-38, https://doi.org/10.1097/00010694-193401000-00003

Yilmaz E. and Nmez M.S., 2017. The role of organic/bio-fertiliser amendment on aggregate stability and organic carbon content in different aggregate scales. Soil Till. Res., 168, 118124, https://doi.org/10.1016/j.still.2017.01.003

Zhang S., Li Q., Ying L., Zhang X., and Liang W., 2013. Contributions of soil biota to $\mathrm{C}$ sequestration varied with aggregate fractions under different tillage systems. Soil Biol. Biochem., 62, 147-156, https://doi.org/10.1016/j.soilbio.2013.03.023

Zhang Y.K. and Schilling K.E., 2006. Effects of land cover on water table, soil moisture, evapotranspiration, and groundwater recharge: A Field observation and analysis. J. Hydrol., 319(14), 328-338, https://doi.org/10.1016/j.jhydrol.2005.06.044 